\title{
見張り支援ニューラルネットワークに関する基礎研究
}

\author{
稲石正明 $* \cdot$ 足立浩一 ${ }^{*} \cdot$ 山下千春 $* \cdot$ 杉崎昭生 ${ }^{*}$
}

\section{Basic Research on a Lookout Support Neural Network}

\author{
Masaaki INAISHI, Kouichi ADACHI, \\ Chiharu YAMASHITA and Akio M. SUGISAKI
}

\begin{abstract}
It is an important solution to construct the lookout support neural network system for navigation at sea in order to raise a ship operation support level. This paper is concerned with a systematization of lookout function and with a picture recognition neural network system for a course and a type of ship estimation.

The neural network topology is three-layered network, which consists of 36 units for input layer, 108 units for hidden layer and 26 units for output layer. Pictures of three-dimensional computer graphics which display ten kinds of ship design drawings are used for supervised training pictures.

The summary of the results are shown below.

(1) The lookout function which consists of a circumstances watch sub-function and a decision making sub-function is shown in a hierarchical block diagram.

(2) Correct recognition rate of the course estimation and the type of ship estimation is $55.5 \%$ and $44.4 \%$ respectively.

(3) Information of a navigational circumstance picture segmentation system building is obtained.
\end{abstract}

\section{1. はじめに}

船舶運航者 (見張り)の視覚機能は、運航の安全を確保するために重要な役割を果たしている。知覚機 能の一っである視覚機能と視覚情報に基づく意志決定機能の一部を機械に置き換えることが可能であるな らば、見張り任務に対する運航者の負担を軽減することができる。本研究は、運航者の視覚機能を用いた 状況監視のための情報の収集および意志決定を支援する画像認識ニューラルネットワークシステムの構築 を目指したすのである。

著者ら (1) は見張り任務で収集される情報の内容を明確にし、航海環境画像から相手船の針路を推定する プロトタイプのニューラルネットワークシステムの構築を行った。システムの評価実験の結果、ネット ワーク学習用のモデル船に対する針路の推定能力に比して、船種が異なる船に対する針路の推定能力が低 いことを明らかにし、針路の推定能力を改善させるためには、相手船の船種を推定する必要があること を明らかにした。

船舶の運航における見張り任務は、単なる監視任務だけでなく、行動計画、評価などの意志決定まで あ含む綜合的な任務と考えることができる。さらに、見張り任務の対象領域は、航海環境だけでなく、 船体、機関、貨物などを含むと考える。このような観点から、見張り任務の機能分類、整理を行い、見 張り支援の内容を明らかにすることが本研究の第一目的である。

*正会員 東京商船大学（T135 東京都江東区越中島 2-1-6) 
相手船の針路之船種に関する支援情報を獲得するために、相手船のシルェット画像の幾何学的特徴から 針路之船種を同時に推定できるニューラルネットワークを構築する。構築したネットワークの推定能力に ついて検討を加え、実用的なシステムの構築へ向けての知見を得ることが本研究の第二の目的である。

これらの目的を達成するために、見張り機能の明確化には、視覚の情報処理モデル(2) (3)などを参考に、 階層的な分類、整理を行い、機能ブロック図としてまとめる。針路と船種の推定には階層型のニューラル ネットワークを用い、学習用の教師画像には日本の代表的な大型船舶の設計図を 3 次元コンピュータグラ フィックス化した画像のシルェット画像を採用する。シルェット画像の幾何学的特徴を入力值として、針 路と船種を出力值としてニューラルネットワークに学習させる。学習猟のネットワークの推定能力の検討 および評価については、航海中の船舶の画像を用いて行う。

\section{2. 見張り機能}

見張り支援の機能内容を明らかにするために、人 間の視覚情報の処理機能に注目して、見張り機能の 分類、整理を行った。見張りの機能ブロック図を図 -1 に示す。見張り機能は目に対応した監視機能お よび脳に対応した意志決定機能に分けることができ る。

監視機能には、船舶が遭遇している状況を監視す る機能と、監視内容 (データ) から状況の認識、理 解を行う二つの機能から成り立つ。状況監視機能は、 自船と相手船以外の環境 (交通環境、地形環境およ び自然環境)の監視、相手船の監視および自船の船 体、機関、貨物状態などの監視機能から成る。相手 船監視機能では主として相手船の探索、追跡および 衝突回避のための遭遇予測を行う。状況認識・理解 機能では、状況監視機能で得られた情報をもとに、 あらかじめ設定されている状況モデルとの照合 (状

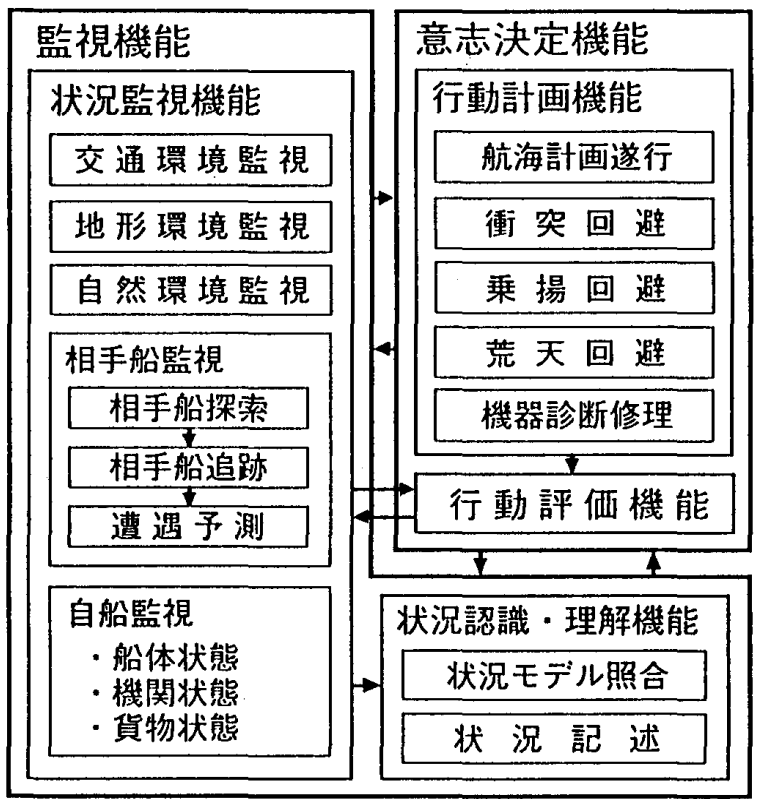

図-1 見張り機能 況モデル照合機能)を行い、あるコード体系で状況 の記述 (状況記述機能) を行う。本研究で構築する針路と船種の推定ニューラルネットワークは、相手船 監視機能々状況認識・理解機能の一部に対応する。意志決定機能は、安全で効率的な運航を行うための行 動計画を行う機能および選択した行動内容などの評価を行う行動評価機能から成る。行動計画機能では、 状況の認識・理解機能で得られた状況記述結果之状況監視機能で得られた情報をもとに取るべき行動計画 を設定する。行動計画機能として、図-1には比較的広い海域の航海に限定した機能を記しており、出入 港や狭水道通過時などに対応した機能を含むことも可能である。行動評価機能では、行動計画の実行に伴 う状況変化の情報 (コード情報)を状況監視機能から集め、行動に対する評価を行う。

\section{3. 針路および船種推定ニューラルネットワークの構築}

\section{3-1 推定方法および構築手順}

相手船の針路と船種の推定は、航海環境画像(1) と画像認識ニューラルネットワークを用いて行う。本研 究では、相手船のシルェット画像から幾何学的特徵(船の長さ、面積など) を抽出し、あらかじめ学習さ せておいた複数のモデル船の特徵との照合により推定する方法を採用した。学習および照合には、階層型 ニューラルネットワークの学習機能拈よび汎化能力 ${ }^{(4)}$ 利用するあのである。

階層型ニューラルネットワークの構築手順 $($ (5) を図 -2 に示す。ニューラルネットワークの構築フェーズは、 教師原画像の収集フェーズ、教師データの作成フェーズ、ネットワーク構造の設計フェーズ、学習 フェーズおよび各フェーズに対する能力評価フェーズの五つのフェーズから成る。 
教師原画像の収集フェーズは、教師データ作成に 必要な原画像の選定と収集を行うもので、システム の汎化能力を左右する重要なフェーズである。教師 データの作成フェーズでは、教師入力及び出力デー 夕を作成する。教師入力データの作成においては、 教師原画像の幾何学的特徴を表す特徽量項目の設定 とその特徴量を 2 值化するためのしきい值の決定作 業がある。教師出力データの作成においては相手船 の針路と船種を出力項目に設定し、各々の出力項目 の值を 2 值化したパターンを教師出力データとする。

ネットワーク構造の設計フェーズでは、教師デー 夕に対応した入出力層のユニットの割当ておよび隠 れ層のユニット数の検討作業を行う。本研究では、 隠れ層のユニット数の決定は推定能力の大小評価に よって行った。学習フェーズでは、バックプロパ ゲーション法により学習を行い、学習終了条件を設 定し、学習結果の検証を行う。

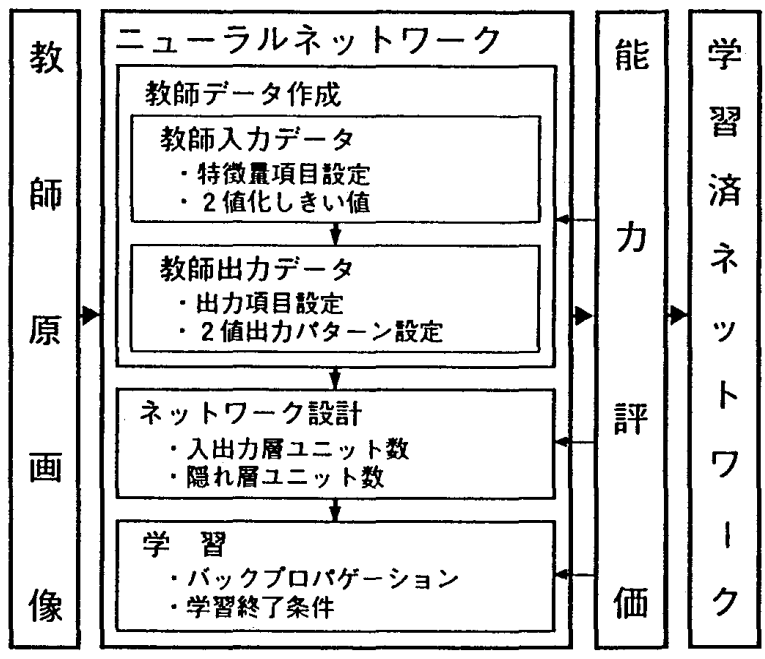

図-2 階層型ニューラルネットワークの 構築手順

能力評価フェーズにおける能力評価方法として、学習のための教師データに存在しない作為的な評価 デー夕に対する能力評価 ${ }^{(6)}$ と、実際の航海環境画像を用いた能力評価がある。本研究では、意味のある作 為的な評価データを作成することが困難であるため、後者の方法による能力評価を行うこととした。

\section{3-2 教師原画像}

教師原画像の作成の手順としては、第一に日本の代表的な大型船舶 10 種類を選び、設計図をもとに喫 水線より上の船体、上部構造物および荷役機械などの座標を読み取り、3 次元グラフィックスソフト SunPHIGS を用いて、3 次元コンピュータグラフィックス画像 (3 次元 CG 画像) を作成する。第二に 3 次 元 CG 画像を 22.5 度毎に回転させ、シルェット画像に変換する。このシルエット画像を教師原画像とし た。 3 次元 CG 画像とすることにより、任意の角度に船体を回転することが可能であり、幾何学的特徴の 算出が計算機 CRT 上の画素単位で行えるなどの利点がある。採用した 10 種類の船舶は船型の類似性より、 次の 6 グループに分けることができる。

(1)鉱石船、鉱撤船、撤物船 (2)コンテナ船、PCC (3)タンカー、VLCC (4)チップ船 (5)LNG 船 (6)客船 最終的に採用できる教師原画像の枚数としては、シルェット画像を利用することおよび船幅の中央に煙突 がない船舶が存在することが原因で、160 画像から91 画像となった。作成したシルエット画像の一例（ LNG 船) を図-3 に示す。

\section{3-3 教師データ}

(1) 特徴量項目

シルエット画像の幾何学的特徴を示す特徵量としては、長さ、面積、図心位置およびシルエット画像 の輪郭線を一つの波形と見なして、フーリエ級数展開した展開式の係数を用いることとした。シルエット 画像の正規化方法 (原図、 $x$ 軸正規化図、 $y$ 軸正規化図、 $x y$ 軸正規化図) および特徴量の無次元化によっ て、 5 種類 36 項目を無次元特徴量項目として採用した。無次元特徴量の定義等を、図一の記号を用いて、 表-1 に示す。表中の○印は識別に採用した特徴量項目である。

(2) 2 值化しきい値および識別マトリックス

設定した各無次元特徴量項目に対して、シルェット画像の画素単位で特徴量を算出する。図心位置は船 体のシルエット画像 (幾何学的図形) の重心に当たるところで、船体部分の画素の密度を 1 として、重心 位置を算出することによって求めることができる。フーリエ級数展開は、表-1に示すように 5 種類の波 形に対して行った。船体の上部輪郭の波形と下部輪郭の波形は、船体の長さ (図-4のOC) を周期として、 右側輪郭の波形と左側輪郭の波形は、船体の高さ(図-4の $O A$ ) 周期としてフーリエ級数展開を行った。 全輪郭の波形とは、上部輪郭の波形 (図-4の abcdef) および下部輪郭 (図-4の ahgf) と図-4の $B C に$ 関し て対称な波形を繫ぎ合わせた波形である。全輪郭の波形に対しては、船体の長さの 2 倍を周期とし、フー 


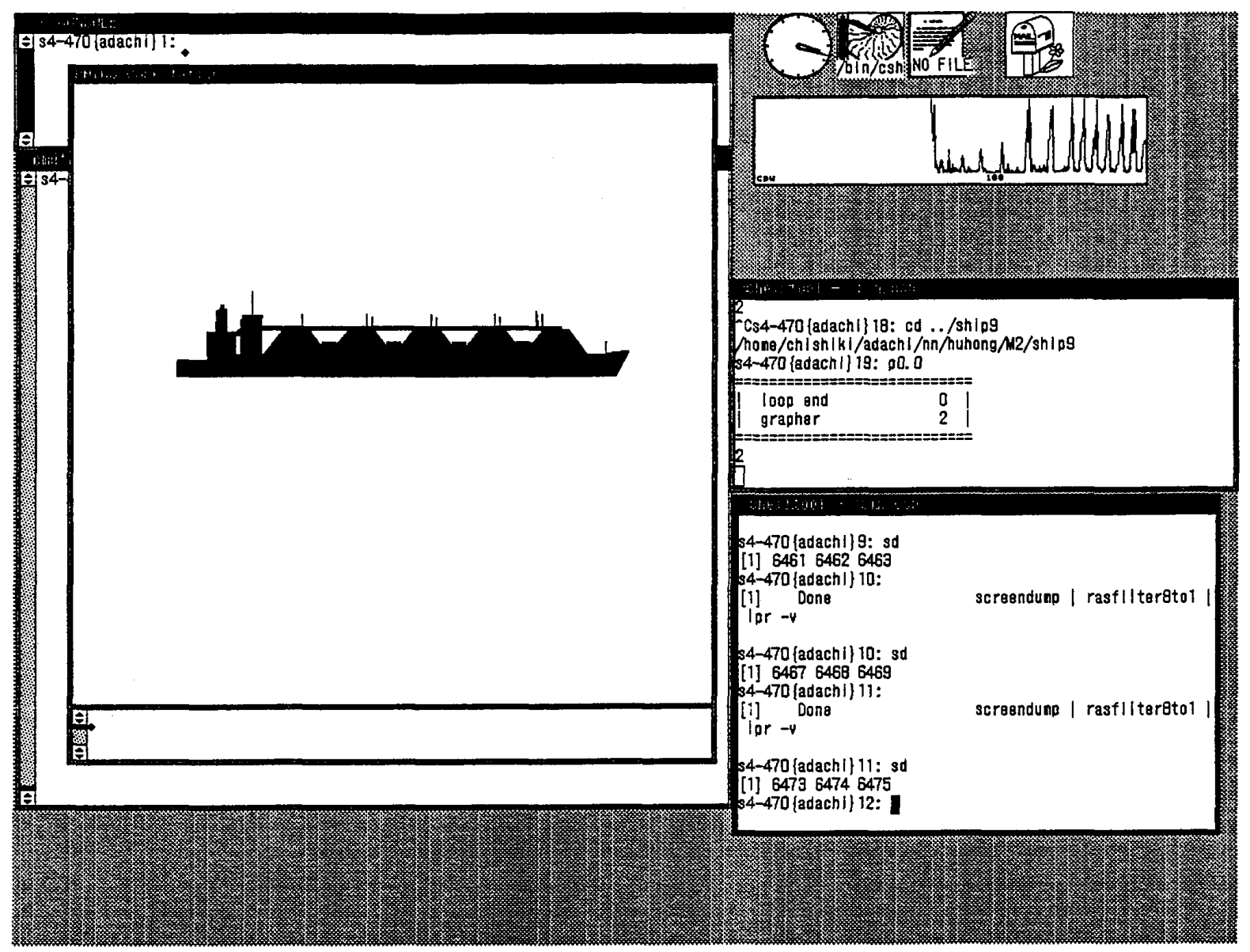

図-3 シルェット画像の一例 (CRT ハードコピー)

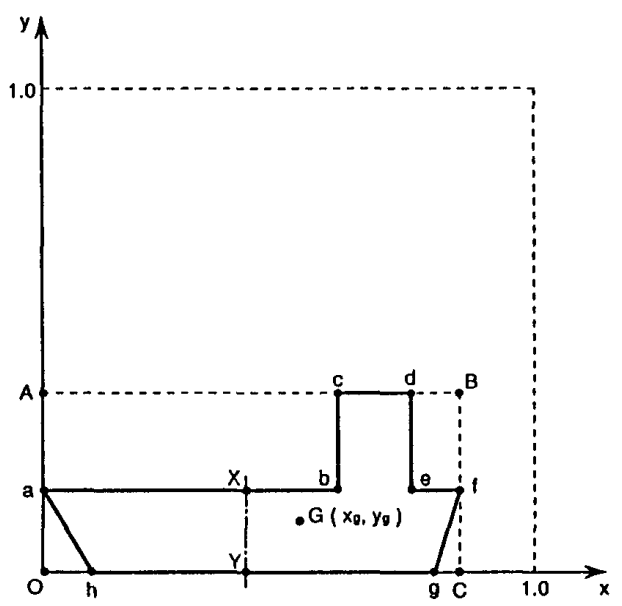

表 $-1 \quad$ 無次元特徵量

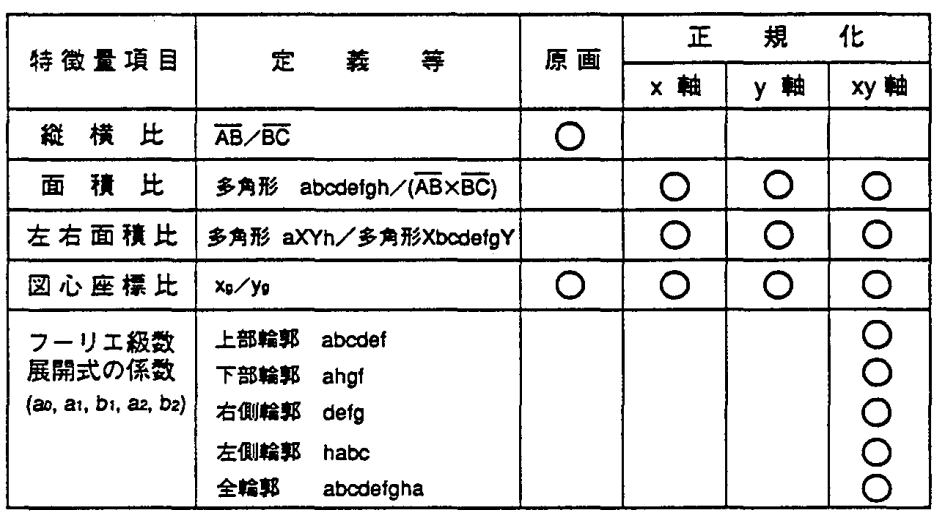

図-4＼cjkstart表-1 の記号説明図

リエ級数展開を行った。各無次元特徴量に対して、2 值化しきい值を用いて 2 值化演算を行った。

2 值化しきい值の決定は、中央法之図-5に示す本研究で開発した調整アルゴリズムを用いて行った。中 央法とは、ある特徴量項目に対する無次元特徴量を昇順に分類し、その順番の中央の値をしきい値とし て採用する方法である。調整アルゴリズムとは、中央法で得られたしきい値を用いて 2 值化した場合、全 ての教師入力データのパターンが異なったデータパターンとならないため、図-5の $K K$ の值を調整して、 中央法で得られたしきい值を調整するアルゴリズムである。調整アルゴリズムの特徽としては、無次元特 
徵量項目の順序に依存しないこと、しきい值の調整 が可能かどうか判断できることなどが挙げられる。 無次元特徵量の項目の数を少なく採用した場合、調 整アルゴリズムの $K K$ の值を変化させても、全て 異なる入力データのパターンにすることができない。 本研究で採用した 36 項目の無次元特徴量は必要最 小限の項目数である。

2 值化された特徵量の列、針路および船種の 3 軸 から成る 3 次元 2 值化識別マトリックスは、針路之 船種の推定の識別空間を表している。2 值化された 特徴量の列がニューラルネットの教師入力データと なり、針路および船種の 2 值パターン列が教師出力 データとなる。

3-4 ネットワーク設計および学習

ネットワークの構造を図-6 に示す。ネットワー クは、入力層、隐れ層および出力層の 3 層から成 る階層型ニューラルネットワークである。入力首に は、無次元特徵量項目の 36 項目に対応した 36 工 ニットを、出力層には、10 種類の船舶に対応した 10 ユニットと 22.5 度毎の針路に対応した 16 工 ニットの合計 26 ユニットを割り当てた。隠れ層の ユニット数は、4-2(2) で述べるように、航海環境画 像の針路の推定能力に優れた、入力層のュニット数 の 3 倍の 108 ユニットを割り当てた。

学習はバックプロパゲーション法により行った。 学習終了条件としては、二乗平均誤差が 0.0025 以 下で、全ての教師データを再現できるまでとした。 学習回数は、隠れ層のユニット数によって異なるが、 1,000 回から 90,000 回を必要とした。

\section{4. 推定能力および考察}

\section{4-1 推定手順}

航海環境画像から針路と船種を推定する手順を図 -7 に示す。航海環境画像としては、東京湾近海を 航海中の船舶をディジタルスチルカメラ(東芝製、 $640 \times 476$ 画素、RGB256 階調) で撮影したディジタ ル画像を用いた。能力試験用の航海環境画像として、 撮影条件が比較的良い18 枚 (6 種類の船舶) の画像 を採用した。

航海環境画像は、画像処理部でモノク口画像に変

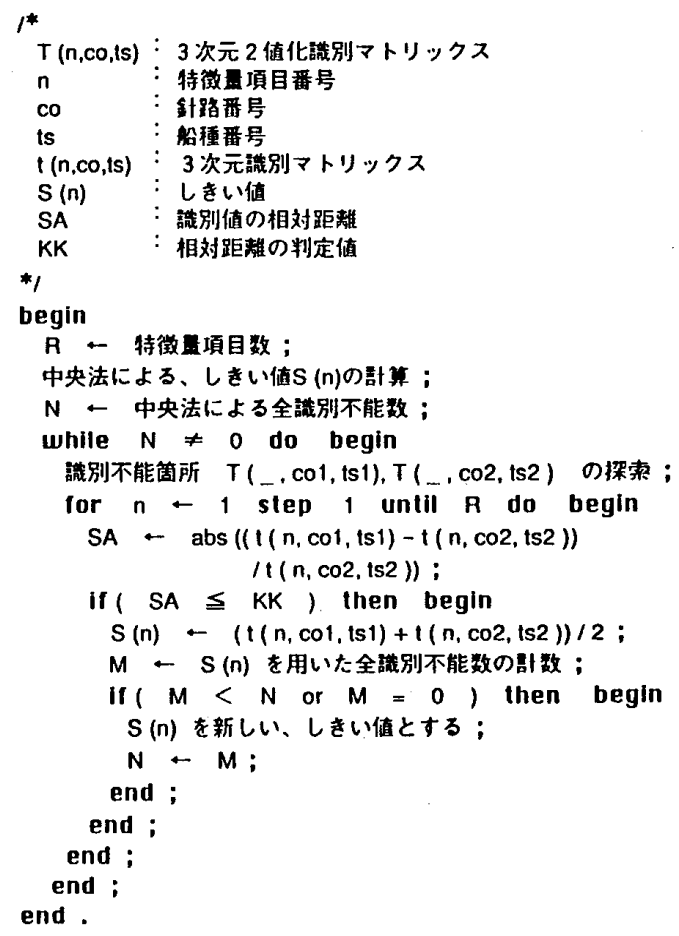

図-5 しきい值調整アルゴリズム

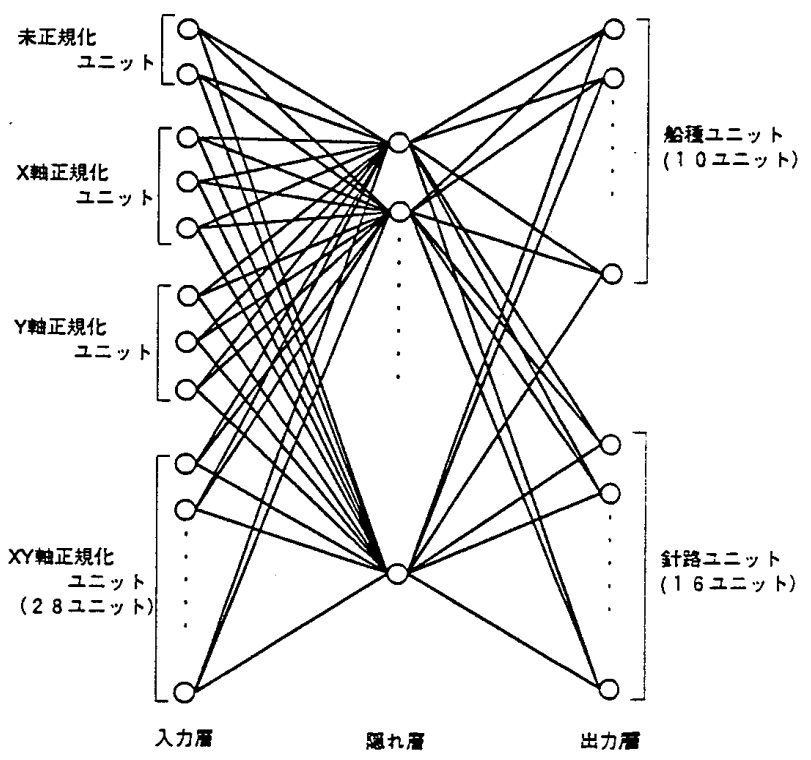

図-6 ネットワーク構造 換する。モノク口変換には、Macintosh 上で動く画 像処理ソフトPhotoshop を用いた。モノクロ変換後、ワークステーション(富士通 S-4/470)に画像デー 夕を転送し、画像のセグメンテーション(切り出し)を支援する特徴点抽出支援システムを用いてシル エット画像に変換する。画像のセグメンテーションに関する多くの研究報告はあるが、航海環境画像から 対象物を認識に適した形で抽出することは、現状では困難であると思われる。本研究では、特徴点抽出支 援システムをC 言語および 2 次元グラフィックスソフトSunGKS を用いてワークステーション上に構築 
した。構築したシステムは、マウスによる特徴点抽出や正規化などを簡単に行えるなどの特徴を持つ。構 築したシステムの機能ブロック図を図-8に示す。

シルエット画像に変換後、教師入力データの作成と同様の手順で、無次元特徴量の算出および 2 值化処 理を行い、ニューラルネットの入カデータを作成する。針路および船種の推定は、学習済ネットワークの 出力データの中で、針路ユニット (16 ユニット)、船種ユニット (10ユニット)それぞれのユニットで最 大值を示すユニットを探索し、そのユニットの位置に対応する針路および船種を推定值とする方法を採用 した。

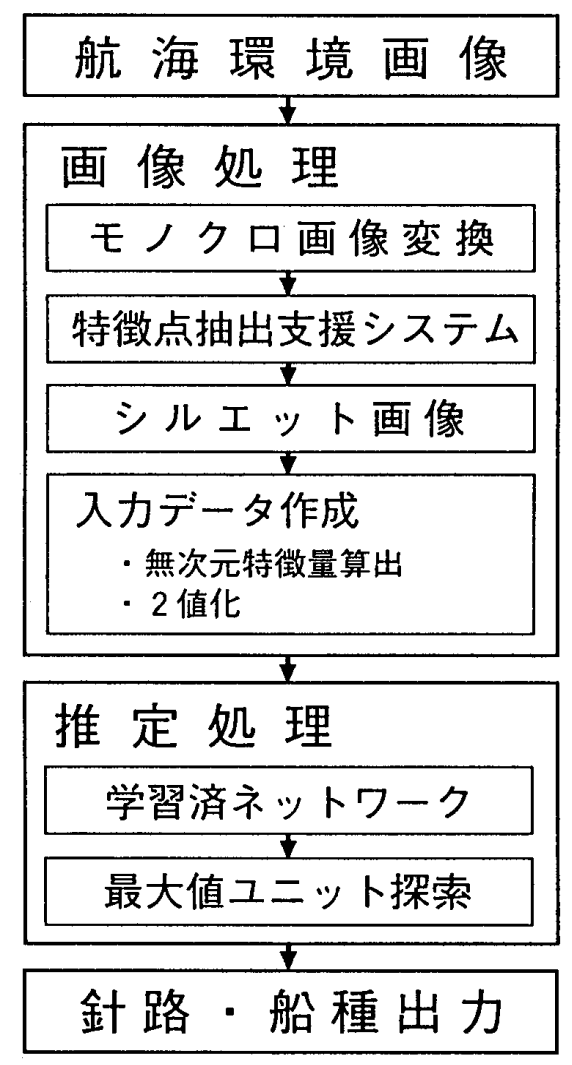

図-7 針路と船種の推定手順

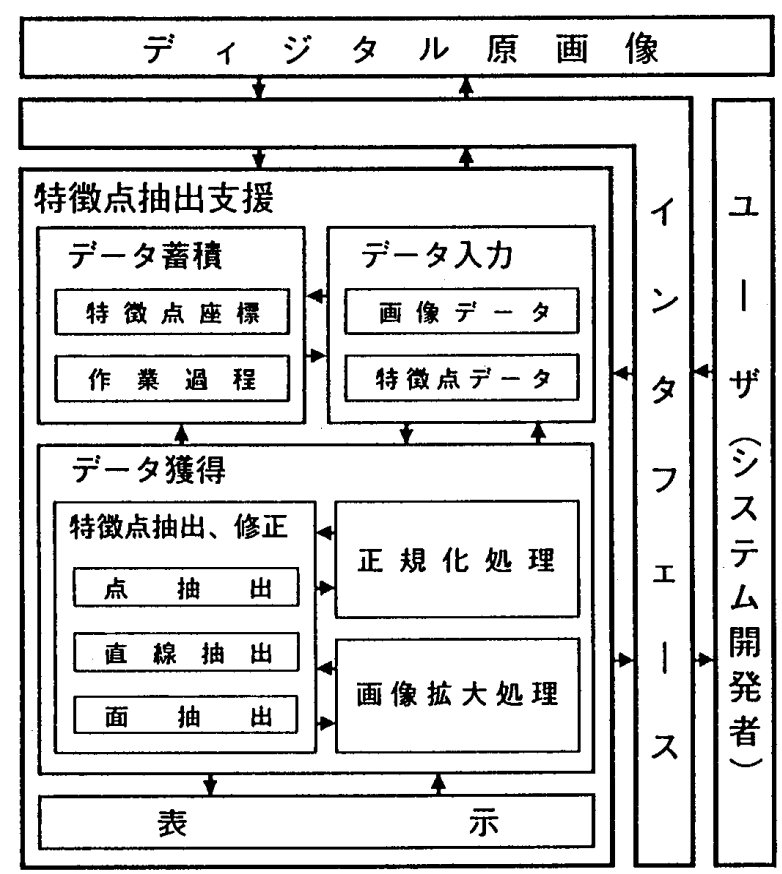

図-8 特徵点抽出支援システムの機能

\section{4-2＼cjkstart推定結果および正解率}

(1) 針路および船種の推定結果

能力試験用の 18 枚の航海環境画像を用いて、針路の推定を行った結果を図-9に示す。縦軸は推定針路 $\theta_{R}$ を、横軸は真の針路 $\theta_{T}$ を示す。眓中のの印は相手船の船種を正しく推定したデー夕を、○印は船種を 誤って推定したデータを示す。前報(1)では、一種類のモデル船を教師原画像に選んで針路の推定を行う ニューラルネットワークシステムであったため、船種が異なる航海環境画像に対する針路の推定能力は極 めて低く、モデル船之異なる船種に対する推定值は、真の針路に関係なく、約 270 度を出力する傾向が あった。本研究では、図-9 に示す様に、傾き 1 の線の近くにばらついており、針路の推定能力がかなり 改善されていることがわかる。また、船種を正しく推定したデータは、針路むほぼ正しい值を示している ことがわかる。

航海環境画像の枚数が 18 枚と少ないが、針路と船種の推定の正解率をまとめたものを表-2 に示す。針 路推定の精度を 16 方位精度とするならば、前報(ネットワークの構造、航海環境画像が本報と異なる)に 比べて正解率は約 40 ポイント改善されている。本研究での船種推定の正解率は約 $44 \%$ 、針路と船種を同 時に正しく推定できる、同時正解率は約 $28 \%$ であった。16 方位精度を 8 方位精度に変えるならば、針路 の正解率は 80\%を越える。また、10 種類の船舶を船型の類似性で、3-2 で述べた様に、6グループに分 けるならば、船種の正解率は約 6 ポイント上昇することがわかり、同時正解率は 16 ポイント上昇する。 
(2) 隠れ層のュニット数と正解率

隠れ層のユニット数によって、ニューラルネット ワークの推定能力は大きく左右される。正解率に及 ぼす隠れ層のユニット数の影響を調べるために、隠 れ層のユニット数を入力層のユニット数の 0.5 倍（ 18 ユニット) から 5 倍(180ユニット)まで、0.5き ざみで変化されたネットワークを用いて学習を行い (入出力層のユニット数は固定、学習終了条件は全 て同じ)、正解率に及ぼす隠れ層のユニット数の影 響を調べた。

ネットワークの全ユニット数 $U$ (入力層のユニッ 卜数 36 、隠れ層のユニット数および出力層のユ ニット数 26 の合計) と能力試験用の 18 枚の航海環 境画像に対する正解率 $R$ の関係を図-10に示す。図 中の○印は針路、 $\triangle$ 印は船種の正解率を、 $\square$ 印は 針路と船種の同時正解率 $R$ を示す。全ュニット数 $U$ が増加しても正解率は増加傾向にはない。ユニッ ト数によって正解率は大きくばらついており、定量 的な関係を見い出すことはできなかった。本研究で は、針路の推定能力が優れ、針路と船種の同時正 解の割合が高い $U=170$ (入力層が 36 ユニット、隠 れ層が $36 \times 3=108$ ユニット、出力層が 26 ユニット )の場合のネットワークを学習済ネットワートとし て採用した。

(3) 特徴点数と正解率

航海環境画像から船体の領域だけを切り出し、シ ルエット画像を作成する方法の一つに原画像中の エッジを用いる方法がある。この方法は原画像中の エッジを全て抽出した後、閉曲線で囲まれた領域を 船体の領域とする方法である。この方法を画素単位 で行う場合、明確な閉曲線が得られないなどの問題 がある。本研究では、エッジに相当する特徴点をマ ウスで選択し、特徴点の抽出を行い、シルエット 画像に変換している。この場合、特徴点の数によっ てシルェット画像が変化し、針路と船種の推定能力 が変化することが予想される。

正解率に及ぼす特徴点の数の影響を調べたものが 図-11 である。椗軸は 16 方位精度での正解率 $R$ 、 横軸は無次元化された特徵点数 $C$ で、図中の○印 は針路、 $\triangle$ 印は船種の正解率を、 $\square$ 印は針路と船 種の同時正解率を示す。無次元特徴点数 $C$ とは、

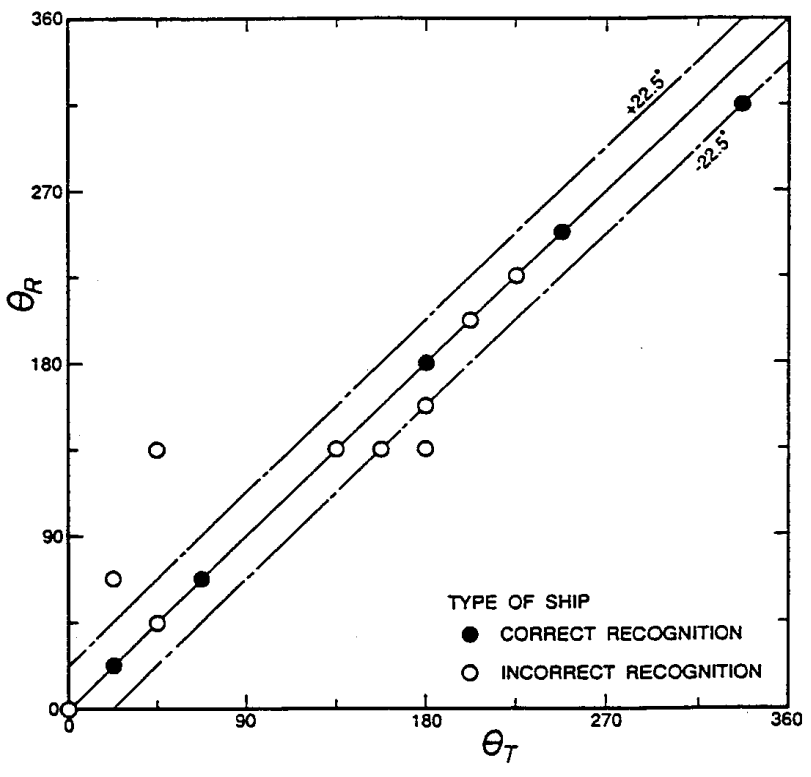

図-9 釬路推定能力

表-2 正解率

\begin{tabular}{|c|c|c|c|}
\hline 正角 & $\begin{array}{l}\text { 前 報 }{ }^{(1)} \\
\text { 16方位精度 }\end{array}$ & $\begin{array}{l}\text { 16方位精度 } \\
10 \text { 種 類 }\end{array}$ & $\begin{array}{l}\text { 8方位精度 } \\
6 \text { 6゙ルーブ }\end{array}$ \\
\hline 針 路 & $14.3 \%$ & $55.5 \%$ & $83.3 \%$ \\
\hline 船 種 & & $44.4 \%$ & $50.0 \%$ \\
\hline 針路十船種 & & $27.8 \%$ & $44.4 \%$ \\
\hline
\end{tabular}

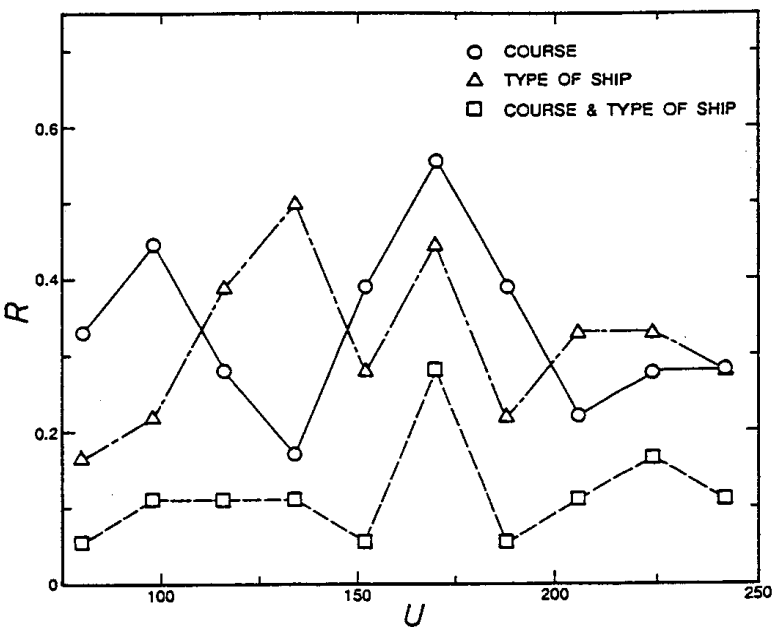

図-10 正解率に及ぼすュニット数の影響 ある特徴点の数と抽出できる最大の特徵点の数の比である。航海環境画像からマウスを使って抽出できる 特徵点の最大数は相手船の針路、画像状態などによって異なる (約 $20 \sim 80$ 点)。C=1.0とは、4-1で述べ た特徵点抽出支援システムで抽出できる最大の点数に対応する。Cの増加によって、僅かであるが、正解 率が増加する傾向にあることがわかる。

船舶運航実務者の意見を参考に、見張り支援のための実用条件を、相手側の針路の推定の精度が 16 方 位精度、正解率が 80〜 90\%以上と設定した。この実用条件を満足するCの值は、図-11 から外挿によっ 
て求めると、約 4 以上であることがわかる。 $C=$ 4.0 とは、本研究で採用した特徽点の数の約 4 倍の 特徵点でシルェット画像を作成する場合に相当する。 本研究で使用した特徵点抽出支援システムを利用す るならば、航海環境画像の撮影用カメラ(約 30 万 画素) の解像度を約 4 倍 (120 万画素)に上げる必要 がある。見張り支援をシステム化するには、高解像 度の撮影装置の利用之航海環境画像に適した画像の セグメンテーション技術の確立および自動化が必要 であり、今後の重要課題と考えている。

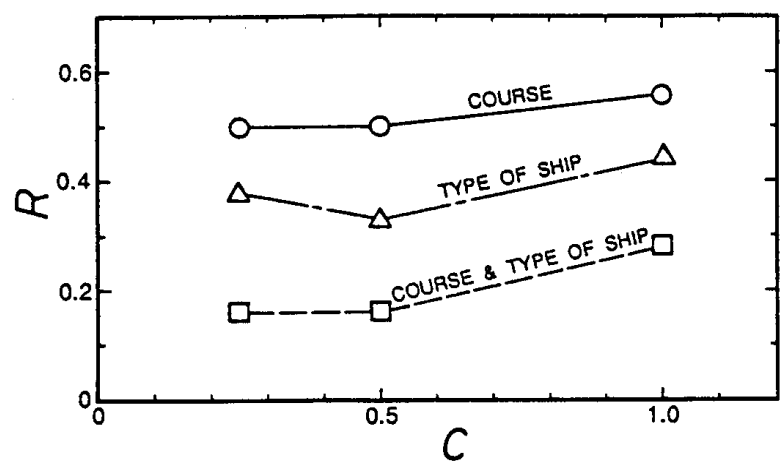

図-11＼cjkstart正解率に及ぼす特徴点数の影響

\section{5. おわりに}

見張り任務を船舶運航の綜合的で中心的な任務ととらえ、見張り機能を分類、整理し、支援内容を明 らかにした。さらに、相手船の針路と船種を同時に推定できる画像認識ニューラルネットワークを構築し、 その能力評価を航海環境画像を用いて行った。

本研究で得られた主な成果を以下に示す。

（1）見張り機能を監視機能および意志決定機能に分けて機能の分類、整理を行い、機能ブロック図とし て示した。

（2）船体のシルエット画像の幾何学的特徵から、針路と船種を推定する画像認識ニューラルネットワーク を構築した。

（3）針路の推定と船種の推定を同時に行うことにより、前報に比して針路の正解率を約 40 ポイント改善 することができた。

(4) 正解率に及ぼすシルエット画像作成のための特徴点の数の影響について考察を加え、撮影装置に必要 な解像度およびセグメンテーションについて知見を得た。

今後の課題としては、画像認識の前処理として、

(1) 航海環境画像の中の認識対象物 (船、物標など) の自動探索に関するシステム化

(2) 認識の対象物に適したセグメンテーション技術の確立および自動化 などが挙げられる。

さらに、針路や船種などの収集情報を基にした状況認識や理解に関連して、

(3) 状況理解モデルの構築

(4) 状況記述方法の検討

などが挙げられる。

本研究にあたっては、東京商船大学大学院生の胡紅瑚君に教師データの作成で多くの協力を得た。(侏郵 船海洋科学の津金正典氏には資料収集にあたり多大の御協力を得た。ここに記して感謝の意を表します。

\section{参 考 文 献}

（1）稲石正明・杉崎昭生：針路推定ニューラルネットワークシステム，日本航海学会論文集, vol.89, pp. $161-168,1993$.

(2) David Marr 著, 乾敏郎・安藤広志訳：ビジョン, 産業図書, 1992 .

（3） K. T.Spoehr, S.W.Lehmkuhle 著, 䒓阪直行他訳：視覚の情報処理, サイエンス社, 1990 .

(4) Rumelhart, D.E., McClelland, J.L. : Parallel Distributed Processing, vol.1, chap.8, MIT Press, 1986.

(5) 稲石正明・杉崎昭生：船舶ニューラルネットワークシステムの構築法とその適用, 日中航海学会学術 講演会論文集, pp.161-168， 1992.

(6) M.Inaishi, H.Matsumura, H.Imazu and A.M.Sugisaki : Basic Research on a Collision Avoidance System Using Neural Networks, International Navigation Congress IAIN'91, pp. $18.1-18.8,1991$. 


\section{質 疑 応 答}

和気博嗣 (神戸商船大学)：船のシルェット以外の船首・船尾の構造波などを判定材料に取り込めないの でしょうか。

稲石正明：シルエット画像を基に相手船の針路の推定および船種の推定を行っていますので、針路が異 なってあ幾何学的に同一のシルェット画像が存在することがあります。この問題を解決する方法の一つ に船種・船尾の構造波を利用することが考えられます。構造波に関する情報 (存在の有無、方向、大き さなど)は、本文の図-1に示した相手船の探索時に、船と船以外の物体の識別に最初に利用することが、 対象物 (相手船など) 探索から意志決定までの判断プロセスに合致したあのだと考えております。相手 船の探索時に得られた情報は、その後の画像認識プロセスで利用することは可能であり、十分利用す る必要があるむのと考えております。

和気博嗣 (神戸商船大学) : 船舶映 (画) 像そのものが気象、海象状況によって判断結果に相当大きく影響 を与えると思うが、その検討は如何でしょうか。

稲石正明: 御指摘の通り、気象・海象状況により撮影条件が変わるため、航海環境画像の色彩、輝度は 理想的な認識に適した画像から大きく異なる場合があると考えております。本研究では、画像の特徵点 を人間の目で確認して抽出しておりますので、少々撮影条件が悪くてもほぼ満足できるシルェット画像 が作成できます。画像のセグメンテーションなどを色彩と輝度を用いて自動的に行う場合には、撮影条 件によって、セグメンテーションの条件を変えるなどの処理が必要であると考えています。

長澤 明 (海上保安大学校)：自動運航等への応用を考える場合、針路の推定法としてはARPA 等の情報 あ有り得る訳ですが、船種の推定については御研究の成果に期待する所が大です。今回、船種として取 り上げられた 10 種の教師データの中に漁船やプレジャーボート等が含まれており、他の一般航行船と の識別制度についての知見が得られていましたらお聞かせ下さい。

稲石正明：本研究では、3-2 で述べました様に、10 種類の大型船を教師データのモデル船として採用い たしました。そのため本報告のネットワークには漁船やプレジャーボート等に対応する出力層のユニッ 卜がありませんので識別はできません。しかし、教師データにその様な船舶をモデル船として含ませる ならば、識別は原理的に可能であると考えております。 